\title{
Assessment knowledge and attitude and practice toward GERD among smoker in Riyadh City, 2018.
}

\author{
Saad Mohammad Alshahrani, Abdullah Odah Alahmari, Abdulaziz Jarallah N Alobaidi \\ Imam Muhammad ibn Saud Islamic university
}

\begin{abstract}
Background: The risk of GERD is significantly associated with smoking which could increase the reflux symptoms.

Objectives: Assessing the knowledge, attitude and practice (KAP) toward GERD among smokers at Riyadh, Kingdom of Saudi Arabia (KSA).

Methods: A prospective randomized controlled study based on a questionnaire sheet that was conducted at Saudi Arabia, from March to July 2018. The study included 390 medical students randomly chosen from different faculties of medicine around KSA.

Results: Most of the subjects have adequate knowledge and good attitude about the GERD disease, its causes, symptoms, the association of drinking and smoking with initiation of the disease and the effect of life style modifications on the management of GERD. The level of practice was inadequate among most of the participants as the majority of them won't stop smoking, change their lifestyle and eating habits even they had GERD.

Conclusion: The Knowledge level was significantly adequate which resulted in positive attitudes among most of the subjects. However, the level of practice was insufficient which may result in impairing the quality of life and increasing the prevalence of the disease.
\end{abstract}

Keywords: Knowledge, Attitude, Practice, Gastroesophageal reflux disease (GERD), smokers, Riyadh, KSA.

\section{Introduction}

Gastroesophageal reflux disease (GERD) is the most common gastrointestinal (GI) diseases among adults around the world especially western and Asian countries ${ }^{(\mathbf{1}, \mathbf{2})}$. It is triggered by an irregular reflux of gastric contents to the esophagus. Its symptoms include indigestion and acid vomiting ${ }^{(3,4)}$.

GERD is not life-threatening but it is associated with impairing the quality of life when compared to other chronic diseases ${ }^{(5)}$. The management of GERD depends on modification of lifestyle factors as obesity, being overweight, eating habits, alcohol drinking and smoking ${ }^{(6)}$.

Many studies have shown that the risk of GERD is significantly associated with smoking which could increase the reflux symptoms ${ }^{(7-9)}$. Also, smoking cessation reduced the prevalence of GERD, reduced the severity of reflux symptoms, and improved HR-QOL ${ }^{(9)}$. This study aimed at assessing the knowledge, attitude and practice (KAP) toward GERD among smokers at Riyadh, Kingdom of Saudi Arabia (KSA).

\section{Methods:}

Study design:

This is a prospective controlled study based on a questionnaire sheet that was directed at Riyadh City, KSA, from May to August 2018. Study population and sample size:

The sample size was determined using the web calculator ${ }^{(10)}$ after taking the total size of Riyadh population ${ }^{(11)}$. The study was supposed to include 240 subjects who were randomly chosen and interviewed in shopping malls distributed at different parts of KSA. The inclusion criteria were Saudi male smokers aged from 20-60.

Study

tools:

The study questionnaire was conducted after reviewing the available studies regarding the definition, risk factors, symptoms, management of the disease and its association with smoking. The questionnaire was revised by 3 experts then translated into simple Arabic, tested in a pilot study among 50 Saudi males then modified and validated. The questionnaire involved 4 parts regarding the demographics' of 
included males, knowledge level, attitude and practice pattern.

\section{Ethical approval:}

The study approved by the ethical committee of Faculty of medicine. The participants provided a written informed consent of their approval.

\section{Statistical analysis:}

The data were processed using the Statistical Package for Social Sciences (SPSS, version 22) for windows. The variables were shown as frequencies and percentages.

\section{Results:}

\section{Demographics of the studied subjects:}

The demographics' of the included subjects were presented in Table 1.

Table (1): Demographics' of included subjects (240)

\begin{tabular}{|c|c|c|}
\hline & Mean \pm SD & Range \\
\hline Age (years) & $31 \pm 4.7$ & $20-60$ \\
\hline \multirow{2}{*}{\multicolumn{3}{|c|}{$\begin{array}{c}\text { Percentage } \\
(\%)\end{array}$}} \\
\hline & & \\
\hline $1-5$ years & 33 & 13.75 \\
\hline 6-10 years & 48 & 20 \\
\hline 11 years or more & 159 & 66.25 \\
\hline \multicolumn{3}{|l|}{$\begin{array}{l}\text { Educational } \\
\text { Level }\end{array}$} \\
\hline College & 213 & $88.7 \%$ \\
\hline $\begin{array}{l}\text { Secondary } \\
\text { School } \\
\end{array}$ & 19 & $8 \%$ \\
\hline Primary School & 8 & $3.3 \%$ \\
\hline \multicolumn{3}{|l|}{ Working status } \\
\hline Employee & 199 & $83 \%$ \\
\hline $\begin{array}{ll}\text { Jobless } & \text { or } \\
\text { retired } & \\
\end{array}$ & 41 & $17 \%$ \\
\hline
\end{tabular}

\section{Assessment of knowledge:}

The study included 240 smoking males in Riyadh where the majority of them have adequate knowledge about the GERD disease, its causes, symptoms and the association of drinking and smoking with initiation of the disease. Also, most of them had significant knowledge about the quality of life during GERD, the effect of life style modifications on the management of GERD.
Table (2): Awareness level among participants (240):

\begin{tabular}{|c|c|c|}
\hline & & Correct \\
\hline & $\begin{array}{l}\text { GERD is a very common } \\
\text { disease of } \\
\text { gastrointestinal tract } \\
\text { among adults. }\end{array}$ & $\begin{array}{c}231 \\
(96.25 \%)\end{array}$ \\
\hline $2-$ & $\begin{array}{l}\text { GERD is caused by an } \\
\text { abnormal reflux of } \\
\text { gastric contents into the } \\
\text { esophagus }\end{array}$ & $\begin{array}{c}165 \\
(68.75 \%)\end{array}$ \\
\hline & $\begin{array}{l}\text { It is characterized by } \\
\text { bothersome symptoms } \\
\text { such as heartburn and } \\
\text { acid regurgitation }\end{array}$ & $\begin{array}{c}189 \\
(87.8 \%)\end{array}$ \\
\hline & $\begin{array}{l}\text { smoking and drinking } \\
\text { habits were associated } \\
\text { with GERD }\end{array}$ & $\begin{array}{c}211 \\
(88 \%)\end{array}$ \\
\hline & $\begin{array}{l}\text { GERD significantly } \\
\text { impairs health-related } \\
\text { quality of life (HR-QOL) } \\
\text { than chronic diseases }\end{array}$ & $\begin{array}{c}239 \\
(99.6 \%)\end{array}$ \\
\hline & $\begin{array}{l}\text { Overweight or obese, and } \\
\text { consuming late evening } \\
\text { meals are risk factors for } \\
\text { GERD }\end{array}$ & $\begin{array}{c}154 \\
(64.2 \%)\end{array}$ \\
\hline & $\begin{array}{l}\text { Lifestyle factors } \\
\text { modifications of smoking, } \\
\text { obesity, and eating habits } \\
\text { are advocated for GERD } \\
\text { management }\end{array}$ & $\begin{array}{c}226 \\
(94.2 \%)\end{array}$ \\
\hline
\end{tabular}

\section{Level of knowledge:}

The awareness level was sufficient among the majority of respondents (Table 3).

Table (3): Level of knowledge regarding GERD:

\begin{tabular}{|c|c|c|}
\hline Knowledge level & Frequency & Percent (\%) \\
\hline Good & 182 & 75.8 \\
Poor & 58 & 24.2 \\
Total & 240 & 100.0 \\
\hline
\end{tabular}

- Evaluating the attitude towards first aid:

The attitude of the most of the subjects was positive toward the effects of GERD on the quality of life and the impact of smoking on GERD level as well as the good prognosis of disease during smoking cessation as presented in Table. 4. 
Table (4): Attitude of medical students toward first aid during spinal injury

\begin{tabular}{|l|c|c|}
\hline \multicolumn{3}{|c|}{ No. $\begin{array}{c}\text { Percentage } \\
(\%)\end{array}$} \\
$\begin{array}{l}\text { GERD can significantly } \\
\text { impair your life }\end{array}$ \\
\hline Yes & 233 & 97.1 \\
\hline No & 7 & 2.9 \\
\hline $\begin{array}{l}\text { The level of smoking } \\
\text { significantly impact the } \\
\text { GERD level }\end{array}$ & 207 & 86.25 \\
\hline Yes toward & 33 & 13.75 \\
\hline No can & & \\
\hline $\begin{array}{l}\text { Tendency smoking } \\
\text { Stopping } \\
\text { result in good prognosis of } \\
\text { GERD }\end{array}$ & 187 & 77.9 \\
\hline Yes & 53 & 22.1 \\
\hline No & & \\
\hline
\end{tabular}

\section{Practice pattern of included subjects:}

The level of practice was inadequate among most of participants as the majority of them won't stop smoking, change their lifestyle and eating habits even they had GERD.

Table (4): practice pattern among medical students:

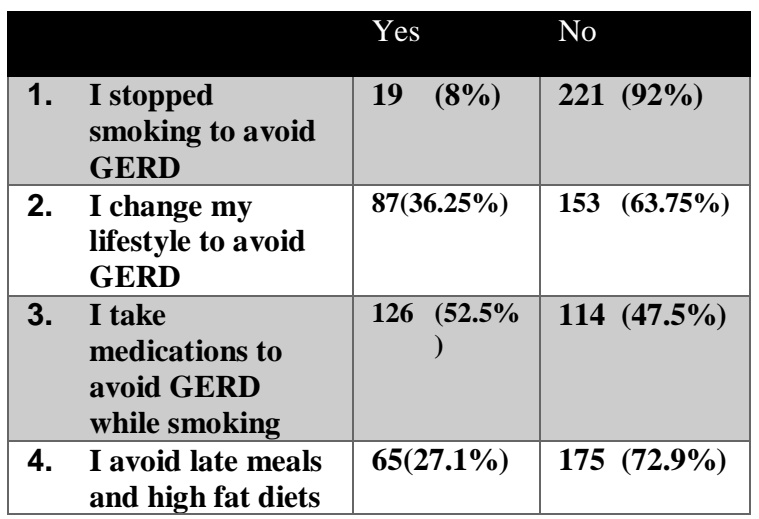

\section{Discussion}

Smoking was found to be associated with gastroesophageal reflux disease (GERD).This study aimed at establishing knowledge, attitude and practice of smokers regarding GERD disease. To our knowledge, this is the first study conducted to measure the awareness of general population about this disease.

However, the level of knowledge was adequate and the attitude was positive among most of the subjects. Most of the participants showed insufficient practice level as even if they were suffering from GERD they won't stop smoking, but they would only use medications without changing the life style. These results were in contrast with the management guidelines of the disease.

This study has also some limitations as the questionnaire didn't include a question about if they suffer from GERD or not and the population size was small due to the short study period. But one strength positive factor in this study was that all the participants were informed after filling the questionnaire about the adequate practice pattern during GERD management.

\section{Conclusion:}

The Knowledge level of the participants was significantly adequate which resulted in positive attitudes among most of the subjects. However, the level of practice was insufficient which may result in affecting the quality of life and increasing the prevalence of the disease.

\section{References:}

1.El-Serag HB, Sweet S, Winchester C, et al. (2014): Update on the epidemiology of gastrooesophageal reflux disease: a systematic review. Gut, 63:871-880.

2.Rubenstein JH and Chen JW (2014): Epidemiology of gastroesophageal reflux disease. Gastroenterology clinics of North America, 43:1-14.

3.Pace F, Bazzoli F, Fiocca $\mathrm{R}$ et al. (2009): The Italian validation of the Montreal Global definition and classification of gastroesophageal reflux disease. European journal of gastroenterology \& hepatology, 21:394-408.

4.Vakil N, van Zanten SV, Kahrilas $P$ et al. (2007): [The Montreal definition and classification of gastroesophageal reflux disease: a global, evidence-based consensus paper]. Zeitschrift fur Gastroenterologie, 45:1125-1140.

5.Shinozaki S, Osawa H, Hayashi Y et al. (2017): Vonoprazan $10 \mathrm{mg}$ daily is effective for the treatment of patients with proton pump inhibitor-resistant gastroesophageal reflux disease. Biomedical reports, 7:231-235.

6.Ness-Jensen E, Hveem K, El-Serag $\mathrm{H}$ et al. (2016): Lifestyle Intervention in Gastroesophageal Reflux Disease. Clinical gastroenterology and hepatology : the official clinical practice journal of the American Gastroenterological Association, 14:175-182. 
7.Fujiwara Y, Kubo M, Kohata $\mathrm{Y}$ et al. (2011): Cigarette smoking and its association with overlapping gastroesophageal reflux disease, functional dyspepsia, or irritable bowel syndrome. Internal medicine (Tokyo, Japan), 50:2443-2447.

8.MacFarlane B (2018): Management of gastroesophageal reflux disease in adults: a pharmacist's perspective. Integrated Pharmacy Research \& Practice, 7:41-52.
9.Kohata Y, Fujiwara Y, Watanabe T et al. (2016): Long-Term Benefits of Smoking Cessation on Gastroesophageal Reflux Disease and Health-Related Quality of Life. PLoS One, 11:e0147860.

10.http://www.calculator.net/sample-size calculator.html type $=1 \& \mathrm{cl}=95 \& \mathrm{ci}=5 \& \mathrm{ps}=3$ $\% 2 \mathrm{C} 976 \% 2 \mathrm{C} 000 \& \mathrm{x}=37 \& \mathrm{y}=6$.

11.ghdx.healthdata.org/.../centraldepartment-statistics-and-informationsaudi-arabia 